\title{
Population size, Red List status and conservation of the Natuna leaf monkey Presbytis natunae endemic to the island of Bunguran, Indonesia
}

\author{
Martjan Lammertink, Vincent Nijman and Utami Setiorini
}

\begin{abstract}
We present the first population estimate for the Natuna leaf monkey Presbytis natunae, endemic to the island of Bunguran, Indonesia, based on a 2-month survey. Bunguran has a land area of only $1,605 \mathrm{~km}^{2}$ and was until 1980 largely covered in primary forest. At present primary forest exists only in small patches within a matrix of logged forest, which covers nearly $70 \%$ of the island. Natuna leaf monkeys are confined to forest and have a preference for primary lowland forest patches. Groups average $3.5 \pm$ SD 2.0 individuals and occur in a density of $2.3 \pm$ SD 1.1 groups per $\mathrm{km}^{2}$. Extrapolation of the density estimates to the entire island indicates that $<10,000$ individuals remain in two subpopulations. On Bunguran these monkeys make popular pets and the
\end{abstract}

species is threatened in part by the demand for captive individuals but mostly by continuing degradation and reduction of forest. An assessment of the species following IUCN threat criteria indicates that it should be categorized as Vulnerable. We make a number of recommendations for the conservation of the species, most importantly the implementation by the district government of Natuna of two strict conservation areas on the island, and the maintaining of a larger area of sustainably used natural forest.

Keywords Bunguran, endemic, Indonesia, logging, Presbytis femoralis, primate, Red List.

Three species of non-human primate are found on Bunguran, slow loris Nycticebus coucang, long-tailed macaque Macaca fascicularis, and Natuna leaf monkey Presbytis natunae. Specimens of the Natuna leaf monkey were first collected by A. Everett in October 1893 and described as a distinct species Semnopithecus natunae by Thomas \& Hartert in 1884. Later taxonomic revisions placed the taxon as a subspecies of more widespread species, Presbytis siamensis (Chasen, 1935; Brandon-Jones, 1984), P. melalophos (Oates et al. 1994; Zain, 2001) or P. femoralis (Chasen, 1940; Whitten 1987). Zain (2001) presented a molecular phylogeny of the genus Presbytis and concluded that natunae split $0.8-0.9$ million years ago from the melalophos-femoralis clade of the Malay Peninsula. Recently, taxonomy has come full circle, with Groves (2001) recognising the Natuna leaf monkey as a valid species, restricted in its distribution to Bunguran.

Several of the 11 species of Presbytis (Groves, 2001) are endemic to single islands. Largely as a result of logging activities several can be considered threatened with extinction, although currently only two $(P$. comata and $P$. potenziani) are recognized as such (IUCN, 2002). Although not formally included in the IUCN Red List, the Natuna leaf monkey is included under P. femoralis and as such is categorized as Lower Risk: near threatened. Mittermeier et al. (2002) acknowledged that little information was available about the conservation status of the Natuna leaf monkey, but nevertheless included the species in a list of the world's 25 most endangered primates. A survey to determine the conservation needs 
and potential reserve areas for the Natuna leaf monkey was identified as a priority by Eudey (1987).

Indrawan \& Rangkuti (2001a, b) carried out a 14-day survey of the Natuna leaf monkey, assessing the current development status of the island and confirming the continued existence of the taxon. Their surveys were qualitative and no population estimates or assessments of habitat preferences were made. The current paper is intended to complement their study in these respects. During a comparative study of woodpecker communities on several islands in the Sunda region, ML and US carried out transect-surveys on Bunguran over a 2-month period. Records were kept of encounters with Natuna leaf monkeys and these form the basis for the findings presented here. The aims of the present paper are: firstly, to report on densities and estimated population size of the Natuna leaf monkey, secondly, to comment on threats facing the species, thirdly, to assess its conservation status using the IUCN threat criteria and, fourthly, to make recommendations for a conservation strategy.

\section{Methods}

\section{Habitat, logging intensity and remaining forest cover}

Between 6 May and 22 July 2001 ML, US and 4-5 assistants conducted fieldwork on Bunguran totaling 54 field-days. An initial 6-day reconnaissance survey was undertaken with the aim of locating the best preserved forest areas on the island. Subsequently, three $4.4 \mathrm{~km}$ transects were cut in forest, one each in the north, centre and south (Fig. 1). To ensure independence of data, the transects were spaced far apart, with the shortest overland distance between transects being $22 \mathrm{~km}$. Two measures of the degree of logging disturbance along the transects were recorded: cut basal area, calculated from the diameter of cut stumps in a $6 \mathrm{~m}$ wide belt along the transect, and the percentage of the length of the transect occurring as patches with or without visible signs of logging (cut stumps, logging roads, skid trails, illegal logging trails and logging gaps), scored per $50 \mathrm{~m}$ of transect length. Forest cover was estimated from satellite imagery (Agency for the development of Natuna island, 2001) and topographic maps (BAKOSURTANAL, 1986), and corroborated by ground-truthing. Four habitat types were distinguished:

(1) Heath forest grows on poor, white-sand soil and is moderately tall with canopy trees reaching 16-29 m and with tree diameter at breast height $(\mathrm{DBH})$ rarely $>30 \mathrm{~cm}$. The forest floor is covered in a thick layer of moss, and pitcher plants (Nepenthes spp.) are abundant. Our reconnaissance surveys and information from island inhabitants indicated that as much as $30-40 \%$ of remaining forest on Bunguran may be heath forest. (2) Primary

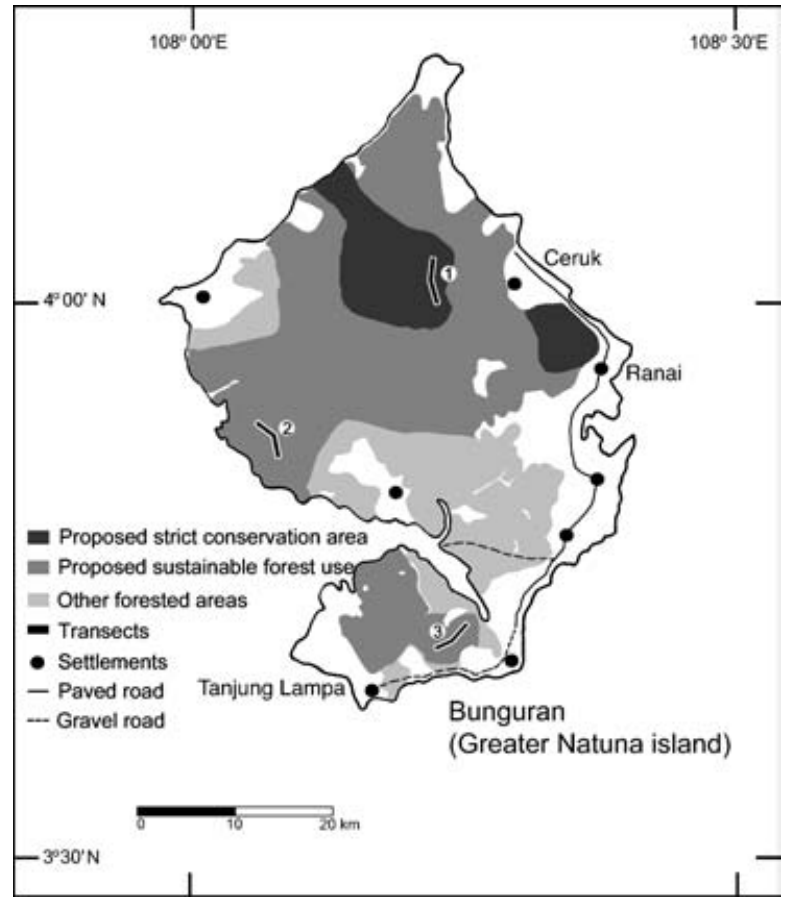

Fig. 1 Island of Burungan, showing the area of remaining forest (shades of grey) in 2001, the proposed strict conservation areas (Bedung in the north-west and Ranai in the north-east), and areas proposed for sustainable use (see text for details), and the three transects used for estimating densities of Natuna leaf monkey Presbytis natunae.

lowland forest and (3) hill forest, with the former on fertile soil in flat or lightly undulating terrain below $200 \mathrm{~m}$ altitude, and hill forest on steeper slopes $(>10 \%)$ at 200-500 m. Maximum recorded tree height and $\mathrm{DBH}$ were 47 and $62 \mathrm{~m}$ and 105 and $130 \mathrm{~cm}$, in lowland and hill forest, respectively. (4) Logged lowland forest has not been clear felled but is still heavily forested with remnant mature trees or unlogged patches within the matrix of logged forest. Many large trees have been removed and there are patches with pioneer trees such as Macaranga and Mallotus. Logging operations were carried out between 1980 and 1996 by three concessionaires on Bunguran, operating from the southern and eastern coasts of the island and reaching far inland (Paizun, pers. comm.). In 2001 no concessionaires were active on the island but illegal logging was widespread. Illegal logging was carried out by numerous small, independent gangs who saw felled trees into beams in situ. The sawn wood is pulled by hand to the nearest road or river and exported directly to Malaysian Borneo (Indrawan \& Rangkuti, 2001b). No palm oil plantations are planned on Bunguran in the near future because transport costs to and from this remote island are high. Forest fires have affected only small areas of logged forest along the main road in south-eastern Bunguran. Small-scale 
rubber groves form the boundary between the natural forest and cultivated land along the populated southern and eastern coastal strips.

\section{Density estimation}

Transects 1, 2 and 3 were surveyed 16, 17 and 15 times, respectively, with a walking speed of $600 \mathrm{~m} \mathrm{hr}^{-1}$, using markers every $50 \mathrm{~m}$ for calibration. Natuna leaf monkeys were located both by sight and by their calls. They call mostly between 04.00 (before sunrise) and 10.00. Upon encounter the estimated location of a group was entered on a map, from which the perpendicular distance to the transect was taken. The total survey time was $414 \mathrm{~h}$. Because our sample size was less than the minimum required to estimate density using distance sampling (Buckland et al., 1993), we estimated densities using a two-belt method (Sutherland, 2000):

Density $=\frac{n_{1}+n_{2}}{2 r l} \log _{e}\left(\frac{n_{1}+n_{2}}{n_{2}}\right)$

where density is in groups per $\mathrm{km}^{2}, r$ =width of the near belt, $n_{1}=$ number of groups encountered in the near belt, $n_{2}=$ number of groups encountered in the far belt, and $l=$ total length of the transect; $r$ was selected so that approximately half the records were grouped in the near belt. This two belt-method is suitable for density estimates based on small sample sizes because it does not require an assumption of the shape of the detection curve (Järvinen \& Väisänen, 1975). Density in individuals per $\mathrm{km}^{2}$ was calculated from group density using the mean group size.
We used a log-likelihood analysis (G-test) to test for differences in the distribution of Natuna leaf monkeys over the four habitat types. Expected values were generated based on a random distribution of groups proportional to the amount of each habitat type along the transects. William's correction to $G\left(G_{\text {adj }}\right)$ was applied for comparisons between habitat types (Sokal \& Rohlf, 1995). Significance was assumed when $\mathrm{P}<0.05$ in a two-tailed test.

\section{Interviews}

Human attitudes towards Natuna leaf monkeys were assessed by semi-structured interviews of $>20 \mathrm{~min}$, in Bahasa Indonesian, with 20 islanders, including five people that kept the species as pet. To ensure independence of data each interviewee was questioned separately.

\section{Results}

Of the three study sites the largest amount of primary forest was found at Bedung in the north (Table 1). Most of this is hill forest; only $12 \%$ of the transect is primary lowland forest, occurring in a continuous stretch adjacent to the hill forest. Inhabitants of Ceruk informed us that a larger area of primary lowland forest exists on the west side of Mount Bedung. On the other two transects primary forest was found in 12 patches of $50-420 \mathrm{~m}$ in length. Logging damage resulted from a mechanical concession operation that removed entire logs in the case of the northern site, but from illegal pit saw logging at the southern site and a combination of both at the central site. Although the quantity of removed timber

Table 1 Forest habitat types (see text for details) and degree of logging disturbance at the three study sites (see Fig. 1) on the island of Bunguran, Indonesia.

\begin{tabular}{|c|c|c|c|c|c|}
\hline \multirow[b]{2}{*}{ Study site } & \multirow[b]{2}{*}{ Forest type } & \multirow[b]{2}{*}{$\begin{array}{l}\mathrm{m} \text { of transect } \\
\text { length }\end{array}$} & \multirow[b]{2}{*}{$\%$ logged $*$} & \multicolumn{2}{|l|}{ Cut basal area } \\
\hline & & & & $\begin{array}{l}\text { Within logged } \\
\text { patches } \\
\left(\mathrm{m}^{2} \mathrm{~km}^{-2}\right)\end{array}$ & $\begin{array}{l}\text { Averaged over } \\
\text { entire transect } \\
\left(\mathrm{m}^{2} \mathrm{~km}^{-2}\right)\end{array}$ \\
\hline 1. Bedung (north) & $\begin{array}{l}\text { primary lowland } \\
\text { primary hill } \\
\text { logged lowland }\end{array}$ & $\begin{array}{r}540 \\
1,760 \\
2,100\end{array}$ & 47.7 & 256.1 & 122.2 \\
\hline 2. Semala (central-west) & $\begin{array}{l}\text { primary lowland } \\
\text { logged lowland }\end{array}$ & $\begin{array}{r}585 \\
3,815\end{array}$ & 86.7 & 632.8 & 548.7 \\
\hline 3. Lintang (south) & $\begin{array}{l}\text { primary lowland } \\
\text { primary heath } \\
\text { logged lowland } \\
\text { logged heath } \\
\text { burnt heath }\end{array}$ & $\begin{array}{r}1,080 \\
850 \\
2,270 \\
100 \\
100\end{array}$ & 56.1 & 404.9 & 227.3 \\
\hline
\end{tabular}

*Percentage of transect length with visible signs of past logging activity, scored per $50 \mathrm{~m}$ section. 
is lower in the logged concession than in the illegallylogged southern area (Table 1), the forest in the concession area had a more damaged appearance, with gaps and pioneer vegetation.

The total remaining forest area on Bunguran was estimated to be $1,091 \mathrm{~km}^{2}$, i.e. $68 \%$ of the land surface of the island. This estimate includes a small amount $(<3 \%)$ of rubber plantations that could not be distinguished on the satellite imagery. The remaining forest is in two discrete fragments, one on the main part of the island $\left(997 \mathrm{~km}^{2}\right)$ and a smaller one $\left(94 \mathrm{~km}^{2}\right)$ on the southern peninsula (Fig. 1), and $95 \%$ of all forest is below $200 \mathrm{~m}$ altitude. The two fragments are separated by a c. $5 \mathrm{~km}$-wide gap of cultivated land.

Natuna leaf monkeys were encountered in all four habitat types (Table 2) and an equal number of groups were detected by sightings or calls. Encounter rates were not equally distributed over the forest types $(G=21.4$, $\mathrm{df}=3, \mathrm{P}<0.001$ ). Natuna leaf monkeys were found significantly more often in primary lowland forest than in the other forest types combined $\left(G_{\text {adj }}=17.5, \mathrm{df}=1\right.$, $\mathrm{P}<0.01$ ) and conversely the species was significantly less recorded in logged lowland forest than in the other three habitat types combined $\left(G_{\text {adj }}=13.1, \mathrm{df}=1\right.$, $\mathrm{P}<0.01)$. Usage of heath forest by Natuna leaf monkeys was in proportion to habitat availability. Natuna leaf monkeys were not observed during brief, non-systematic surveys that included habitat types other than those covered by the transects: non-forested areas, rubber plantations, and montane forest near the summit of Mount Ranai.

Table 2 Total survey effort by forest habitat type (see text for details), encounter rates with groups of Natuna leaf monkeys Presbytis natunae, and expected encounter rates if monkeys were equally distributed over habitat types.

\begin{tabular}{lccc}
\hline Forest type & Effort $(\mathrm{m})$ & $\begin{array}{l}\text { Groups } \\
\text { observed }\end{array}$ & $\begin{array}{l}\text { Groups } \\
\text { expected }\end{array}$ \\
\hline Heath & 9,450 & 1 & 1.7 \\
Primary hill & 14,960 & 3 & 2.6 \\
Primary lowland & 16,465 & 11 & 2.9 \\
Logged lowland & 62,165 & 3 & 10.9 \\
\hline
\end{tabular}

Encounter rates differed between morning and afternoon hours $\left(\mathrm{G}_{\mathrm{adj}}=15.4, \mathrm{df}=1, \mathrm{P}<0.01\right)$, with 17 out of 18 encounters before 11.00 (Fig. 2); subsequent analysis of densities is therefore based only on morning surveys. Using $25 \mathrm{~m}$ as the width of the near belt $(r)$ the density of Natuna leaf monkeys was $2.3 \pm$ SD 1.1 groups per $\mathrm{km}^{2}$ (range 1.2-3.4) and average group size was $2.9 \pm$ SD 1.5 individuals. As this does not differ significantly from the $4.0 \pm$ SD 2.3 individuals reported by Indrawan \& Rangkuti (2001b), and because we want to obtain a population estimate that is island-wide and the mean of potential periodical influences, the data were combined, yielding an average group size of $3.5 \pm$ SD 2.0 individuals and a density of $7.8 \pm$ SD 3.7 individuals per $\mathrm{km}^{2}$.

Although heath forest was under-represented on our transects $(8 \%$ of total transect length, whereas it is an estimated $30-40 \%$ of the Bunguran forest cover) encounter rates did not differ between heath forest and logged lowland forest, the predominant habitat types on Bunguran. We therefore consider extrapolation from transect densities to the total Bunguran forest justified. Estimates of the number of groups and individuals in the northern and southern forest fragments are summarized in Table 3.

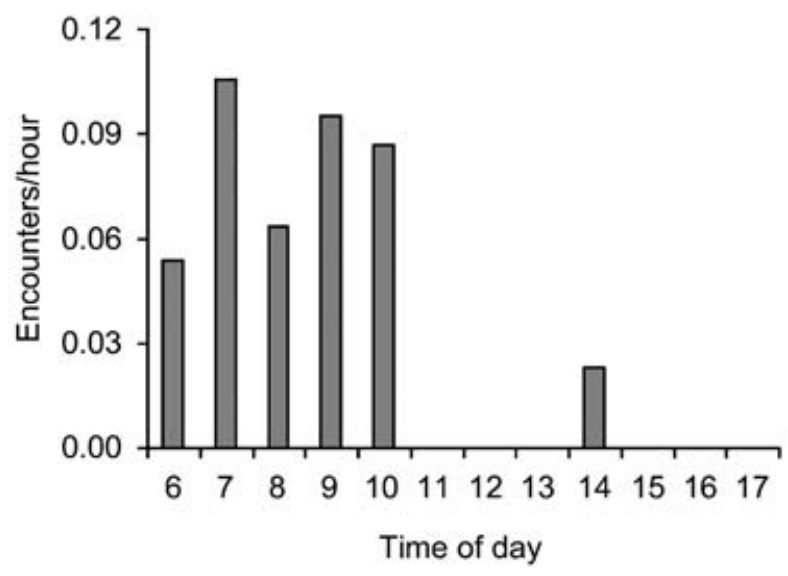

Fig. 2 Encounter rates with Natuna leaf monkey Presbytis natunae according to time of day, showing that nearly all encounters were before 11.00 (based on 414 survey hours and a total of 18 encounters).

Table 3 Estimates of the number of groups and number of individuals of Natuna leaf monkey Presbytis natunae in the two forest fragments (Fig. 1).

\begin{tabular}{lccc}
\hline & & \multicolumn{2}{c}{ Population estimates $( \pm 1$ SD $)$} \\
\cline { 3 - 4 } Forest fragment & Area $\left(\mathrm{km}^{2}\right)$ & Number of groups & Number of individuals \\
\hline North & 997 & $2,293(1,196-3,390)$ & $7,777(4,088-11,466)$ \\
South & 94 & $216(113-320)$ & $733(385-1,081)$ \\
Total & 1,091 & $2,509(1,309-3,710)$ & $8,510(4,473-12,547)$ \\
\hline
\end{tabular}


Natuna leaf monkeys are rarely hunted, as they are not perceived as pests, nor are there any indications that they are hunted to obtain valued bezoar stones (visceral secretions found in some species of Presbytis that are used in traditional medicine and are highly priced). Five Natuna leaf monkeys were found held as pets by villagers or local government officials (Plate 1). We looked for pets only in the main populated area around Ranai and Ceruk; in all likelihood more pets were held on the island, but extrapolations are not possible because we do not know how many households were covered by the networks of informants who told us of pets. Three of the pets were juveniles of 1-12 months of age and two had reached near-adult size. According to the people interviewed juveniles can be reared as pets, but captured adults can also be held in captivity and become relatively tame. The lifespan of these pets is usually $<1$ year for juveniles, but longer for individuals captured as adults. Most monkeys are captured haphazardly near settlements or in forest gardens (a forest

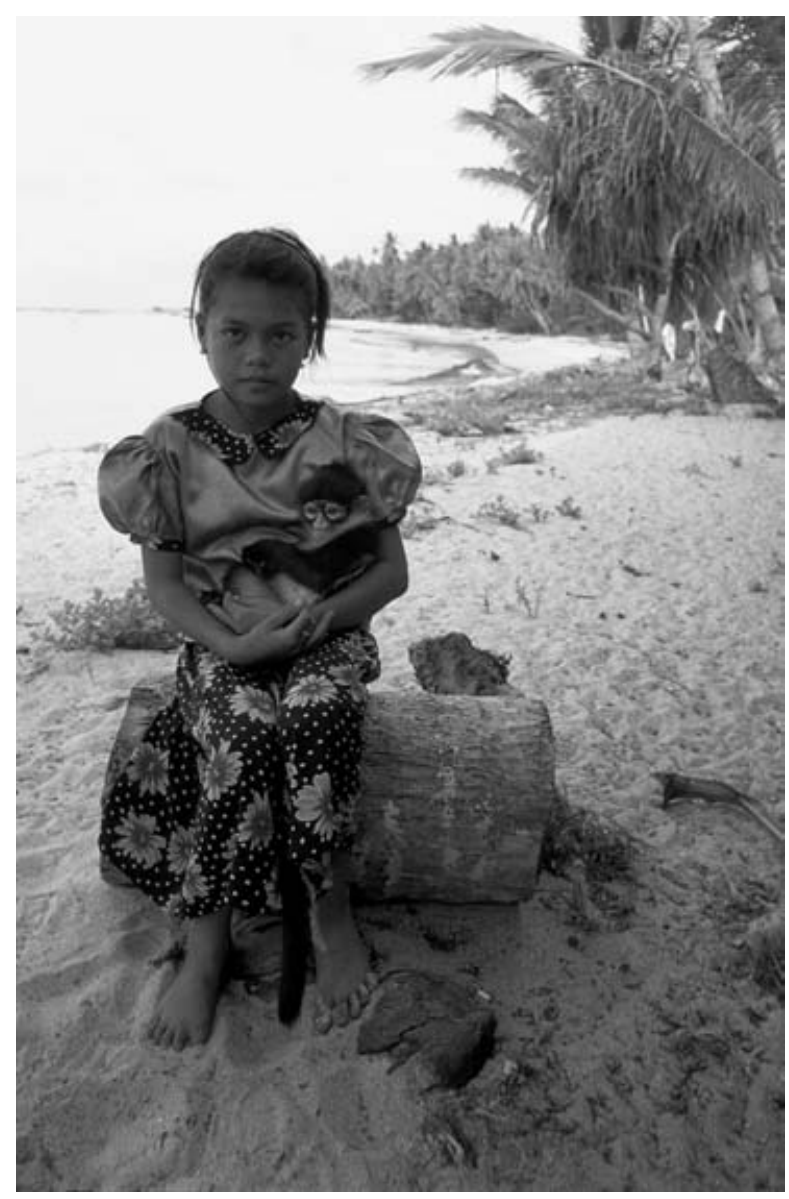

Plate 1 Natuna leaf monkeys Presbytis natunae make popular pets on the island of Bunguran and would be an ideal flagship species for the promotion of wider biodiversity conservation (photo M. Lammertink). patch near a village enriched with planted fruit trees, sugar palms, and occasionally rattan and rubber trees); no capturing forays are undertaken in the forest interior. This is in contrast to the trapping of hill mynas Gracula religiosa and several species of large pigeons, an activity that is carried out on a professional basis by several islanders and takes place in all parts of the island.

\section{Discussion}

Like most of its congeners (Bennett \& Davies, 1994) the Natuna leaf monkey has a preference for primary forest over logged forest, but occurs in a range of habitats, including heath forest and rubber groves. Densities of Natuna leaf monkeys were at the lower end of the range reported for the genus. Whether this is intrinsic to the species or due to habitat disturbance remains unclear. Although we only recorded Natuna leaf monkeys below $260 \mathrm{~m}$, the type specimen was collected at $>600 \mathrm{~m}$ on Mount Ranai (Thomas \& Hartert, 1894) and Indrawan \& Rangkuti (2001b) observed the species at 600-650 m, indicating that it occupies nearly the entire altitudinal range of the island. Densities probably decrease with increasing altitude, as in other leaf monkeys (Nijman \& van Balen, 1997; Nijman, 2001).

Group sizes were small in comparison with other members of the genus, which typically occur in groups of 6-15 individuals (Bennett \& Davies, 1994; Nijman \& van Balen, 1997). Group sizes could have been underestimated as most groups were watched for only 5-10 minutes, but our findings were similar to that of Indrawan \& Rangkuti (2001b). Only the monogamous Mentawai Island leaf monkey Presbytis potenziani occurs in similar group sizes (Watanabe, 1981). Small group sizes may be related to the absence of feline predators on Bunguran, allowing the species to forage more efficiently with less within-group competition.

Hunting of Presbytis leaf monkeys for consumption is widespread throughout their range of occurrence, but is often restricted to certain tribal or religious groups associated with inland settlements or the timber industry (Bennett et al., 1987; Nijman, 2001). On Bunguran hunting of Natuna leaf monkeys is rare or absent as the human population largely adheres to Islamic consumption restrictions, which include primates, and there are no indications that the species contains bezoar stones, which could otherwise encourage hunting. Indrawan \& Rangkuti (2001b) reported that some individuals may get caught in cages set for long-tailed macaques, which are generally perceived as pests, but numbers are probably low as the Natuna leaf monkey is much more arboreal than the macaque.

Like certain parts of Sumatra, but unlike Java or Borneo, people on Bunguran consider leaf monkeys 
to make excellent pets. Although the number of pet captive animals we observed was small, for each captive individual most likely one or several others have died. We have no data on the 'turn-over' of pet Natuna leaf monkeys, but owners reported that captive leaf monkeys have a short lifespan. As large ferries call at Bunguran four times per month and it is frequented by trading vessels and has a large military presence, the species is most likely traded via these channels. Natuna leaf monkeys have been kept in Javan zoos (V.N., pers. obs.). Trading of Natuna leaf monkeys will inevitably increase the demand for these pets.

We found that Natuna leaf monkeys were most often observed in patches of primary forest within the matrix of selectively logged forest. We interpret this as a preference for primary forest and infer that, as c. $30 \%$ of the island is converted into cultivated land and occupied by villages and the remaining forest is now largely selectively logged, population numbers must have declined as a result. Indrawan \& Rangkuti (2001b), on the contrary, concluded that, as they observed Natuna leaf monkeys mostly in old rubber groves, secondary forest and forest gardens, the species main habitat is not primary forest. Because they did not quantify survey effort in each habitat, however, we believe that the sightings in these man-made habitats cannot be interpreted as evidence for habitat preference. Islanders were also of the opinion that Natuna leaf monkeys are most abundant in forest gardens, but this may again be an effect of more time being spent by the observers in these habitats, as well as better visibility in forest gardens and at forest edges. The extent of forest gardens on the island is small, whereas lowland forest is far more important in terms of land cover, is under pressure from logging, and its suitability as habitat for the Natuna leaf monkey is likely to be further degraded. Thus conservation efforts should concentrate on the forested areas, which will also benefit biodiversity on the island in general.

To put the current population size of the Natuna leaf monkey in perspective, it is necessary to make an assessment of the species' historical population size. There are no indications that the species ever occurred on any of the other islands in the Natuna archipelago and hence the species evolved on an island of $c .1,605 \mathrm{~km}^{2}$. If Bunguran was covered entirely in primary forest (Paizun, pers. comm., asserted this was largely so before 1980) and if the monkeys occurred in this, their preferred habitat, at a density of 2-3 times that found in the present study (i.e. 15-20 individuals per $\mathrm{km}^{2}$, as they would probably reach higher densities in large, continuous stretches of primary forest), the total maximum population must have been $c$. 30,000. At present some $30 \%$ of the island comprises non-forested land, in which the species is absent. We estimated that c. 2,500 groups exist in the remaining forest (Table 3) with an average group containing 3.5 adult individuals; this implies that only c. 8,000 mature individuals remain (Table 3 ). The species population size may have declined by $>50 \%$ over the past 25 years.

Indrawan \& Rangkuti (2001ab), on the basis of recording Natuna leaf monkeys in a range of habitats, concluded that the species is not immediately threatened with extinction. On the basis of our study, and applying the IUCN threat criteria (IUCN, 2001), we conclude that the Natuna leaf money should be categorized as Vulnerable on the IUCN Red List (IUCN, 2002), as it is facing a high risk of extinction in the wild according to two criteria: B2ab(iii,v), i.e. area of occupancy $<2,000 \mathrm{~km}^{2}$, with estimates indicating a population occurring at $<10$ locations (a), and a continuing decline (b) in area, extent and quality of habitat (iii) and number of mature individuals (v), and $\mathrm{C} 1+2 \mathrm{a}(\mathrm{ii})$, i.e. population estimated to be $<10,000$ mature individuals, with a continuing decline of $>10 \%$ within the next three generations (c. 20-30 years) (1) and a continuing decline in numbers of mature individuals (2), with all individuals in a single subpopulation (a(ii)). Thus, contrary to Mittermeier et al. (2002) our data suggest that, although threatened, there is little basis for inclusion of the Natuna leaf monkey on the list of the world's 25 rarest primates.

The threatened status of the Natuna leaf monkey necessitates the development of a conservation strategy. Based on our results and conclusions, and bearing in mind that boundary assessment would be required and agreements would need to be reached with stakeholders and the district government, we make suggestions for allocation and management of protected areas. Indrawan \& Rangkuti (2001b) argued that conservation efforts for the Natuna leaf monkey should focus on conserving mixed gardens and rubber plantations, as well as the hill forest of Mount Ranai. These aims should not be difficult to attain, as the future of forest gardens will be secure without additional conservation effort, while the steep hill forest of Mount Ranai already has the status of protection forest and is a watershed forest for the district capital Ranai. However, our findings indicate primary lowland forest to be the preferred habitat of the Natuna leaf monkey, and this is the most important habitat for much of the biodiversity of the island. We propose that conservation efforts need to be also focused on protection of the largest remnants of primary forest, and on allowing logged lowland forest to recover to old-growth conditions. The most suitable area for this is the area around Mount Bedung, including the lowlands west and east of the mountain (Fig. 1). This proposed protected area is $c .50 \mathrm{~km}^{2}$ and could hold a population of c. 350 mature Natuna leaf monkeys. No 
more logging, either by concessionaires or illegal gangs, should be allowed in this area. The highest part of this area, the mountain of Bedung, already has the status of protection forest, although this is not enforced, with illegal logging taking place in the foothills on the eastern side of the mountain (M.L. and U.S., pers. obs.). It would be advisable to include an extension to the coast in this proposed strictly protected area, in order to have a representation of the coastal ecosystem within the protected areas of Bunguran. An extension to the apparently unpopulated area north-west of Bedung may be most suitable, although further fieldwork would be required to confirm this. We agree with Indrawan \& Rangkuti (2001b) that, for general biodiversity conservation, the Mount Ranai area also requires conservation because this includes the only montane forest on the island. The lowlands around Mount Ranai are densely populated and intensively utilized, however, and cannot serve as a suitable alternative to Bedung for protection of lowland forests.

Indrawan \& Rangkuti (2001b) argued that establishment of protected areas as National Parks or Strict Nature Reserves on Bunguran would be counterproductive, as assignment of such status by the central government of Indonesia would be at odds with the increasing desire for autonomy by the district of Natuna. Moreover, centralized conservation bodies are faced with lowered budgets and have become increasingly ineffective. We agree with this analysis and recommend that the regional government of Natuna take responsibility for the biodiversity of the island and support a conservation department to guard and manage the areas proposed for strict conservation. Because of a large-scale gas exploitation project in the seas of this district, Natuna is one of the wealthiest districts in Indonesia, and the instalment of a modest but wellsupported local conservation agency should be possible. The agency would need to cooperate with local stakeholders, including NGOs, businesses, police and the armed forces. In view of its charismatic appearance (Plate 1) and the sympathetic position taken by the islanders towards it, the Natuna leaf monkey would make an excellent flagship species (Bowen-Jones \& Entwistle, 2002) for the overall biodiveristy conservation of Bunguran.

Apart from the two proposed strict conservation areas, we recommend keeping a large part of the currently remaining forest cover on Bunguran as natural forest (Fig. 1), with only a limited amount of sustainable harvesting of timber allowed. The amount of timber to be exploited annually should be agreed upon between local communities and the Natuna district government, and prevention of exploitation beyond the agreed limit should be overseen by the island government. The current unregulated activities of illegal logging bands, often from outside Natuna, should be halted. In view of the small size and vulnerability of the distinct Bunguran forest ecosystem, we argue that further transmigration projects to the island should be discouraged.

\section{Acknowledgements}

Thanks are due to the Indonesian Institute for Sciences (LIPI), the provincial branch of the Forestry Department (SBKSDA), and the local government (KABNAT) of the Natuna regency for permission to conduct our research. Financial support was received from the Netherlands Organisation for Scientific Research (NWO), the Treub Maatschappij and the Van Tienhoven Stichting. For help and support we thank Dr Dewi M. Prawiradilaga, Prof. Dr. Steph B.J. Menken, Ed Colijn, Jan Vermeer, Mohammed Indrawan, Pak Nan, Deni Yudiawan, Mohammed Irham, Paizun and Ijun.

\section{References}

Agency for the development of Natuna island (2001) http:/ / www.bp3n.go.id [accessed 6 August 2003]. BAKOSURTANAL (1986) Peta Rupabumi Indonesia, lembar 1319-20 Ranai. BAKOSURTANAL, Cibinong, Java, Indonesia.

Bennett, E.L. \& Davies, A.G. (1994) The ecology of Asian Colobines. In Colobine Monkeys: Their Ecology, Behavior and Evolution (eds A.G. Davies \& J.F. Oates), pp. 129-171. Cambridge University Press, Cambridge, UK.

Bennett, E.L., Caldecott, J., Kavanagh, M. \& Sebastian, A. (1987) Current status of primates in Sarawak. Primate Conservation, 8, 184-187.

Bowen-Jones, E. \& Entwistle, A. (2002) Identifying appropriate flagship species: the importance of culture and local context. Oryx, 36, 189-195.

Brandon-Jones, D. (1984) Colobus and leaf monkeys. In The Encyclopaedia of Mammals, Vol. 1. (ed. D. Macdonald), pp 398-408. Allen and Unwin, London, UK.

Buckland, S.T., Anderson, D.R., Burnham, K.P. \& Laake, J.L. (1993) Distance sampling. Chapman \& Hall, London, UK.

Chasen, F.N. (1935) On a collection of mammals from the Natuna Islands. Bulletin of the Raffles Museum, 10, 5-42.

Chasen, F.N. (1940) A handlist of Malaysian mammals. Bulletin of the Raffles Museum, 15, 1-209.

Eudey, A.A. (1987) Action Plan for Asian Primate Conservation: 1987-1991. IUCN/SSC Primate Specialist Group, Gland, Switzerland.

Groves, C.P. (2001) Primate Taxonomy. Smithsonian University Press, Washington, DC, USA.

Indrawan, M. \& Rangkuti, F. (2001a) Status des NatunaLangurs auf den Natuna-Inseln. Zoologische Gesellschaft für Arten- und Populationsschutz Mitteilungen, 17, 20-21.

Indrawan, M. \& Rangkuti, F. (2001b) Development, biodiversity and the conservation status of Banded Langur in Natuna Islands, Indonesia. Tropical Biodiversity, 7, 151-163. 
IUCN (2001) IUCN Red List of Threatened Species. 2001 Categories \& Criteria (version 3.1). IUCN, Gland, Switzerland [http://www.redlist.org/info/categories_criteria2001.html, accessed 15 July 2003].

IUCN (2002) 2002 IUCN Red List of Threatened Species. IUCN, Gland, Switzerland [http://www.redlist.org, accessed 15 July 2003].

Järvinen, O. \& Väisänen, R.A. (1975) Estimating relative densities of breeding birds by the line transect method. Oikos, 26, 316-322.

MacKinnon, K., Hatta, G., Halim, H. \& Mangalik, A. (1996) The Ecology of Kalimantan, Indonesian Borneo. Periplus, Singapore.

Mittermeier, R.A., Konstant, W.R., Rylands, A.B., Ganzhorn, J., Oates, J.F., Butynski, T.M., Nadler, T., Supriatna, J. \& Padua, C.V. (2002). Primates in Peril. The World's Top 25 Most Endangered Primates. Conservation International, Washington, DC, USA.

Nijman, V. (2001) Forest (and) Primates: Conservation and Ecology of the Endemic Primates of Java and Borneo. Tropenbos Kalimantan Series 5. Tropenbos Foundation, Wageningen, The Netherlands.

Nijman, V. \& van Balen, S. (1997) A faunal survey of the Dieng mountains, Central Java, Indonesia: status and distribution of endemic primate taxa. Oryx, 32, 145-156.

Oates, J.F., Davies, G.A. \& Delson, E. (1994) The diversity of living colobines. In Colobine Monkeys: Their Ecology, Behavior and Evolution (eds A.G. Davies \& J.F. Oates), pp. 45-74. Cambridge University Press, Cambridge, UK.

Obserholser, H.C. (1932) The birds of the Natuna Islands. Bulletin of the United States National Museum, 159, 1-137.

Sokal, R.R. \& Rolph, F.J. (1995) Biometry. The Principles and Practice of Statistics in Biological Research. 3rd edition. W.H. Freeman, New York, USA.
Sutherland, W.J. (2000) The Conservation Handbook: Research, Management and Policy. Blackwell, Oxford, UK.

Thomas, O. \& Hartert, E. (1884) First glimpses of the zoology of the Natuna Islands III: List of the first collection of mammals. Novitates Zoology, 1, 652-660.

Thomas, O. \& Hartert, E. (1885) On a second collection of mammals from the Natuna Islands. Novitates Zoology, 2, 489-492.

Watanabe, K. (1981) Variation in group composition and population density of the two sympatric Mentawaian leaf monkeys. Primates, 22, 145-160.

Whitten, A.J. (1987) The Presbytis of Sumatra. Primate Conservation, 8, 46-47.

Zain, B.M.M. (2001) Molecular systematics of the genus Presbytis $\mathrm{PhD}$ thesis, Columbia University, New York, USA.

\section{Biographical sketches}

Martjan Lammertink has studied the status of old-growth forests and associated birds in Cuba and Mexico and, from 1997 to 2001, the disturbance responses and community ecology of woodpeckers in Indonesia.

Vincent Nijman has studied the ecology and conservation of Indonesian primates and, since 1994, he has been conducting research on birds and mammals in Indonesia and has been active in implementing conservation activities in Java.

Utami Setiorini studied forestry in Indonesia, and from 1999 to 2001 she worked with the Indonesian woodpecker project of the University of Amsterdam. 